\title{
Improvement will Come from Industry Leaders in Global Financial Structure
}

\author{
Rahat Sabah \\ Department of Commerce, Bahauddin Zakariya University, Multan, Pakistan \\ Email address: \\ rahatsabah@gmail.com
}

To cite this article:

Rahat Sabah. Improvement will Come from Industry Leaders in Global Financial Structure. International Journal of Accounting, Finance and Risk Management. Special Issue: Global Financial Structure. Vol. 5, No. 2, 2020, pp. 84-92. doi: 10.11648/j.ijafrm.20200502.13

Received: February 19, 2020; Accepted: March 9, 2020; Published: April 14, 2020

\begin{abstract}
In this study, I aim to give special emphasizes on the status of Industry Leaders. I want to highlight the role of ignored but crucial associations specifically, Panel of Scholars, Groups of Donors, Research Clusters, Export Processing Zones Associations, Chambers of commerce \& Industries Association, Experienced Business Professionals and Educational Institutions in shaping the global financial structure. Their involvement has great importance in the procedure of financial growth, because they have the power to answer the present change and to capture the current development in the business world. My purpose to examine the global financial structure was not to going behind the schedule but to focus on the power and importance of industry leaders and discover the solution of how to help the deprived citizen, how to use and manage the natural resources and what the motives of financial structure to shape it in better form. I want to make the Industry Leaders conscious about their supremacy, so that they could guide the both developed and developing countries to increase the international flow of capital and enlarge the earning through plenty of natural resources present in our universe, so that nobody would die without medicine and every one could get education in our world.
\end{abstract}

Keywords: Industry, Difficulties, Capitals

\section{Introduction}

When a poor woman died in my home town in 2016, for the reason that. her husband could not arrange some money to pay to the doctor for her treatment, then I realized that, I am the responsible of her death because, being a specialist of business education, I never spoke about the financial issues of 5000 people of my village with my associates and other donors of my village. I never made any strategy to bring them out from poverty; I never thought how to guide them in earning and saving their money. I never told them how to work, where to work and what to work and how to raise their flow of their capital. Than I have to think, why I am getting education? Do we study for ourselves only? Or do we study to distribute our knowledge? If yes, who they are? During my research, I came to know that, millions of Scholars, Researchers, Economist, and academic Scientists, are devoting their lives in searching the Philosophy of wealth and creating concepts, to protect the Priceless individuals on Earth and get them out from poverty. They are working day and night to manage the risks associated with their business and investments. The purpose to analyze the global financial structure is to learn and find out the different techniques and to discover the solution of fallowing question.

How Industry leader could bring the improvement in the global financial structure?

The logical association of the material obtains from the Google Scholars, Academia, Research Grate, working papers and World Bank reports help me to answer the above question as, improvement will come, when industry leaders take the responsibility to manage the business world and started to work in a systematic collaboration with the other economic actors to create $\&$ save wealth resources. The grate vision of Journal of Accounting, Finance and risk Management (Science Publishing Groups) give strength to my thought and provide me a different look in the financial structure to complete my research work.

Since the human history, the economic activities have been the essential part of human life. They are working and traveling for the creation of wealth for their social satisfaction and psychological pleasure. God has also granted higher status to those people, who struggle for goods than on 
those who do not work (sit at home). According to the Tom C. Corley there is a big different between the daily activities of poor people and rich people. He studied 233 rich people and 128 poor people and identified "haves" and "have not's" in the daily activities of both type of people [1], McGregor had also express hop, that his book' Human Side of Enterprise' would helped in developing decision-making strategies to manage the people of an organization [2]. I aim is to make the industry leaders realize that they can change the habits of poor people and poor nations through educating about the importance of hard work and about the awareness of plenty of natural resources present on earth. The above mentioned theory gives the idea that this model of work could be used not only for organization but also for societies and nations. It's understandable that the people of developing nations do not want work and don't have healthy habits.. The expansion of international financial market has become the fundamental idea in the last decades. Resources should be travel across the boundaries after some restrictions and regulations [3]. In the same way Communal gain from worldwide risk sharing may help to make clear discovery of empirical learning about international capital mobility [4]. I wait for that industry Leaders could make ready these nations to develop their habit of work and help them how to work, where to work and what to work.

\subsection{Financial Resources Are Not Scarce in the World}

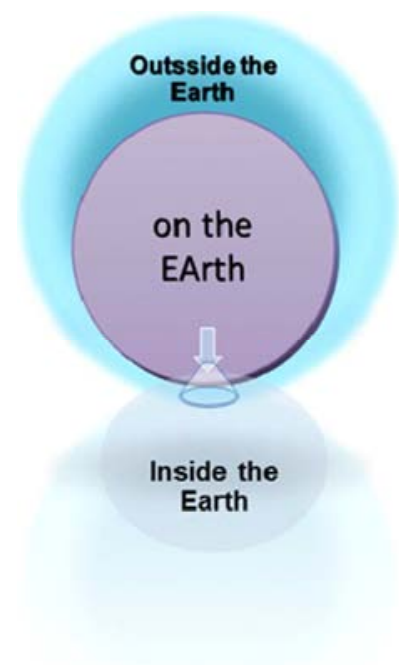

Figure 1. Resources present in the Universes.

Resource of wealth is present everywhere in the universes. People just need to know, where to seek and how to use these resources. Everything present in our world could be used to carry out the moneymaking activities, for example to produce, to create, to construct, to assemble, to grow, to explore and to invent another things. Straw, clay, air, water, color, fragrance, flower, plants, forest, Desert, river, sea and sun have their value and mean of income. Everything has different and many means of income. Straws (grass) have its prices and it is uses in many line of business, such as food of some animal, to beautification of lawn, parkland, outbuildings and to enkindle the furnace. In the past, there was no idea to sell the sunlight. Mr. Edmond Becquerel has found photovoltaic effect and told us, how we could generate the electricity from the light of sun [5] and Park N. G developed higher efficiency macroscopic solar cells which include perovskite and dye-sensitized solar cells [6].

\subsection{Varieties of Financial Resources.}

\subsubsection{Financial Resources Outside the Ground of Earth \\ i. Planetary \\ ii. Environmental}

\subsubsection{Financial Resources on the Ground of Earth}
i. Agricultural Resources
ii. Industrial Resources

\subsubsection{Financial Resources Inside the Ground of Earth \\ i. Organic \\ ii. Inorganic}

Financial resources are not too far away from the reach of the people, these are near enough to be detected or collected. We need to consider and think about the things that are present in the vast universe for our use. Every country in this global village have its own land, own water and own space, No hurdles in the way to seek and search of sources of income and earnings as much as we need. We could get benefit from all the things present in the universe if, we want. There is no restriction on us by any bodies or authorities. Hamilton has said that the countries which have used their natural resources become independent and able to raise their capital such as Botswana. $\mathrm{He}$ also suggested that management of natural resources is an important part of development strategies [7].

\subsection{Paths of Financial Wealth}

Financial wealth does not have a single path, it is the total of all the procedures by mean an individual or Nation perform their economic activities to make and gather fortune from the environment in which they live. People can be guided to bring the natural resources into useful form. Money matters are strongly related with field of education. Everyone needs to learn this art individually as well as countrywide. Scholars, study scientists and researchers can guide the people to bring the natural resources into useful form. Wealth a return and reward of human efforts, which are done to spend a relaxed life by fulfilling their basic needs.

Some people are able to fill simply small part of their wants by generating labor and numerous have the ability to fill the needs of many other people. In recent times the apex management starts thinking about that management should work for makes profit for shareholders, managerial theory and business policies are impressed by agency theory [8]. But seeking and maximizing wealth is not the aim of life of the people, while economic activities are performed to fulfill the social needs of people, So that they could catch the real aim of their lives When people learn how to seek and use the resources, how to work for earning, they not only become able to raise their own income but they could help others also 
to generate income.

\section{Different Techniques to Improve the Financial Structure}

Important and valued groups of Scholar, Academic Scientists could build the confidence of Charitable Organization, Experienced Business Professionals, Free Trade Zone Authorities, Human Development Associations and other economic actors have better understanding about the current global business requirements and challenges. They could play a vital role in the financial development process with the fallowing ways and means.
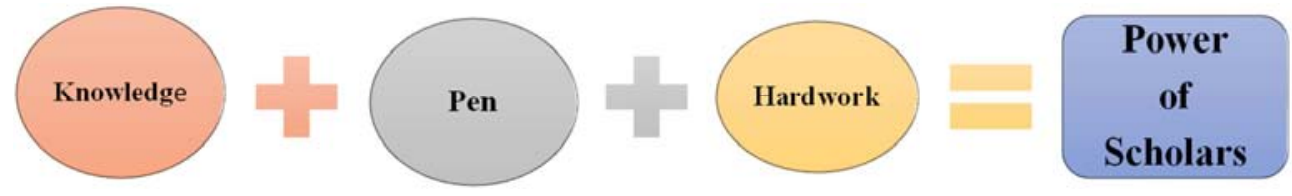

Figure 2. Power of Scholars.
As they having the highest status on earth, so this is their duty to guide the people toward the right direction not only regarding the business and earnings but taught them social and moral ethics also. The worth mentioning work of Scholars could help others through spreading knowledge about work and learn. Their knowledge should be reachable to every one if, they want to work for whole people on earth.

\subsection{By Developing Global School of Financial System}

Electronic learning management system is become popular day by day. Private or government Institutions are busy to

\subsection{By Means of Power}

Scholars, study scientists, are the blessing on Earth. They are not like the uneducated and unknown people in the world. Human need weapons of knowledge to fulfill their desire of increasing money and trade. The power completely comes at what time when we recognize and then apply it to our lives again and again. "Knowledge is power" and knowledge is key to success" [9], is showing the path to them to create their own field of exercises in the financial system. With the help of knowledge and pen, they could have appreciated impact on economic activities and possibly will change the techniques of happening in the business world. establish branches of their organizations in the world, with the same way electronic education system of business education could be established. The teamwork of the industry leaders is very important and necessary to bring the learners in one standard of education. They could take best care of issues regarding the inflow of International capital around the globe. Not only they could manage the businesses activities of world significantly with their scope and presence but could give batter representation of global business opportunities and challenges to educational institutions.

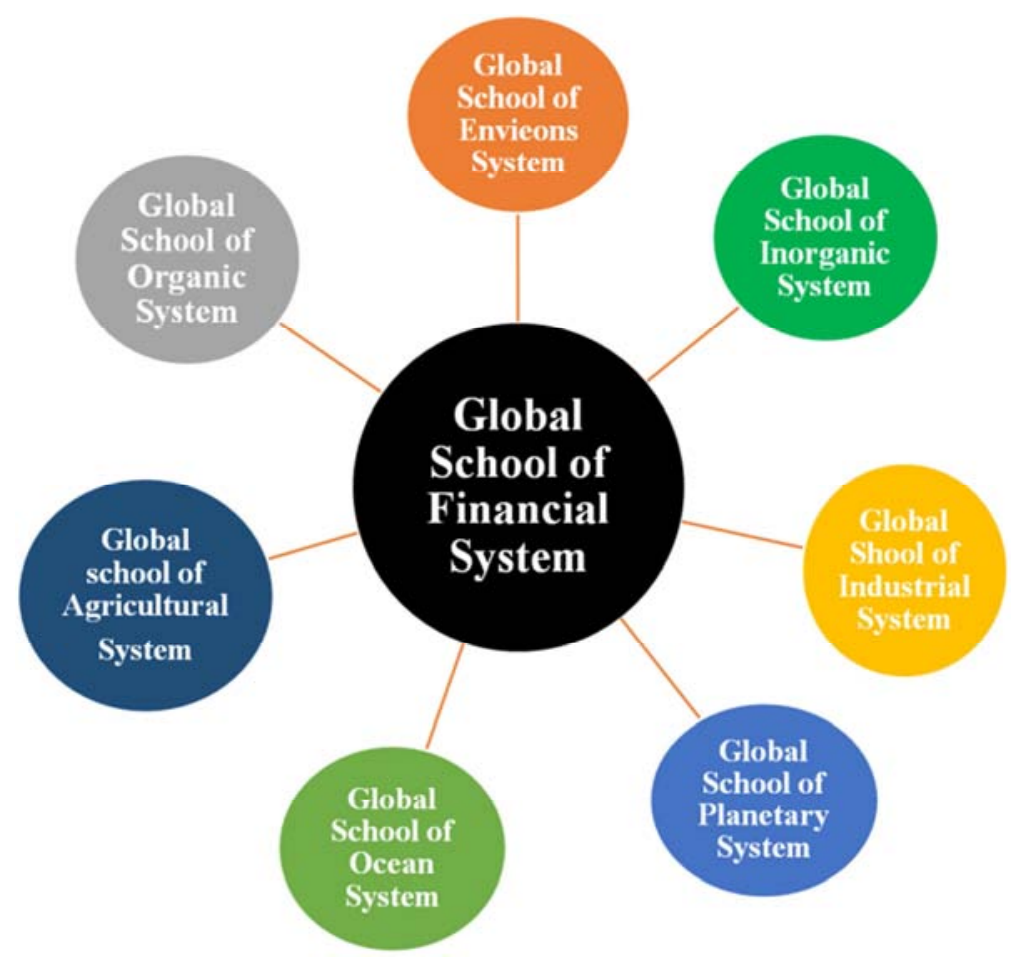

Figure 3. Global School of Financial System. 
The worth of student's knowledge and educational experience closely link with the engagement with their study and educational community in which they are learning. It is very important what student do outside the university, many student have work with studies these students often could not prepare their class work and increase missing of class [10]. Development of global school of business will help the students, teachers, and governments regarding the new opportunities in the field of business and science. The school of business could make the student able to get the opportunities of work to help many people of their community, when they learn abbot the uses of resources and philosophy of work and wealth.

\subsection{By Opening Resources Research Center}

Formation of financial resources research centers could help to research, to discover, to study, to explain, to categorize, to calculate, to explain, to predict and to control the financial resources present in different area. Research about the Nature and Behavior of financial resources would enable the industry leaders to create opportunities of many business and investments. Every country should establish research center in its every city and then a national research center. So that the resources could be identify for sale and exchange within the countries as well as in the International market. These research centers would bring the students and industry leaders very close to produce knowledge and implement it business world, outside the research site.

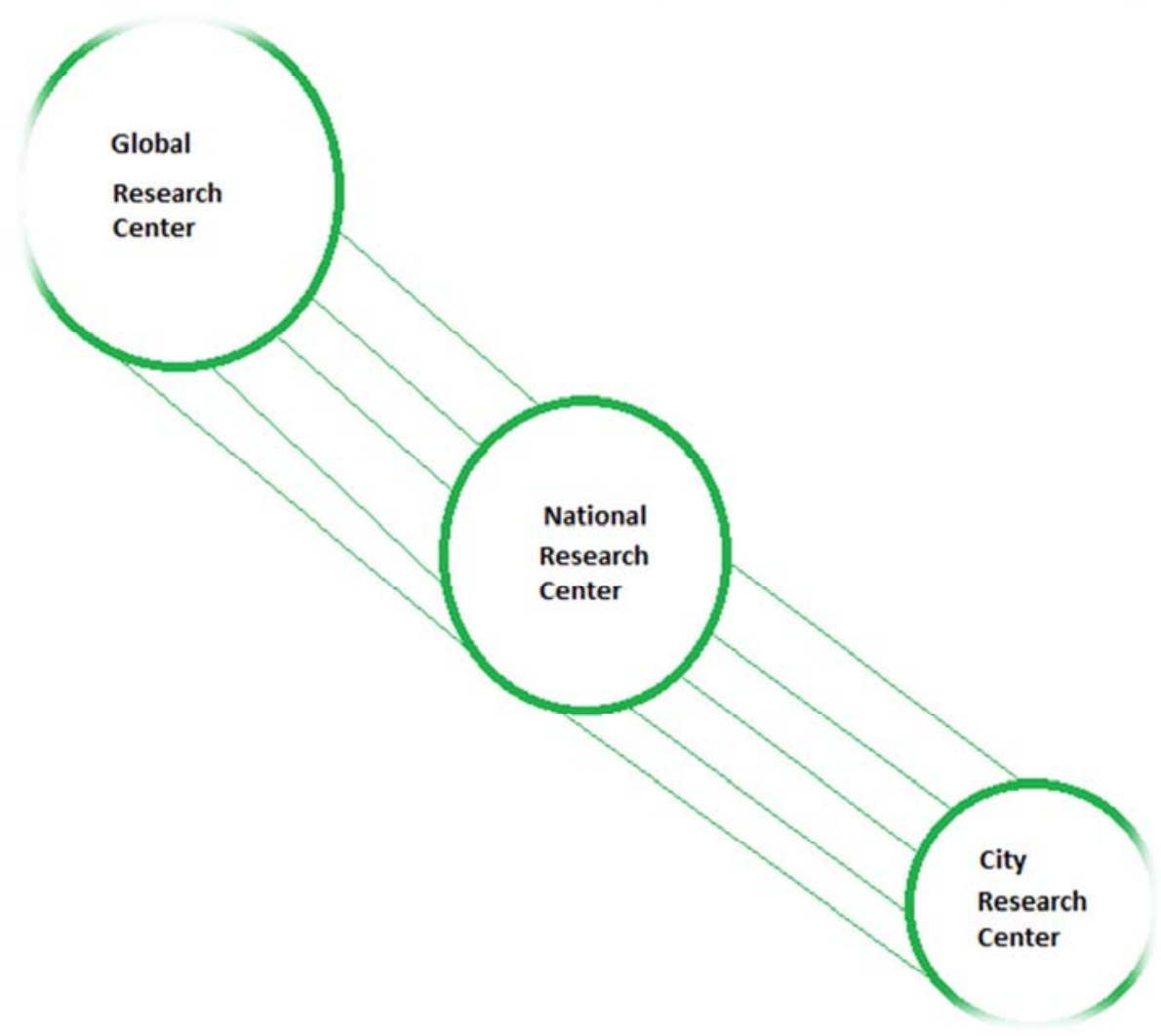

Figure 4. Financial Resources Research Centers.

When research was immature than our economics and business was very simple. Some companies together introduce the financial realities and set aside an enough budget to establish industrial research institute. From that time much has been taught and discover about the financial resources management. The knowledge and money have travel analogous increase in knowledge become cause to increasing of money [11]. The nation, who began to ignore the new opportunities of business, investments, Industry, technology, skills, dealing and studies as result they have to face the scarceness because of unused of resources.

\subsection{By Opening Industry T. V Networks}

T. V program through digital streaming is becoming popular now a days. Now students and teachers are using You Tube videos for learning and teaching. It has become very important to use this technology into providing information to the general public. Network of $\mathrm{T}$. $\mathrm{V}$ of industry Leaders could play a vital role to update the all associations comprise the financial structure. 


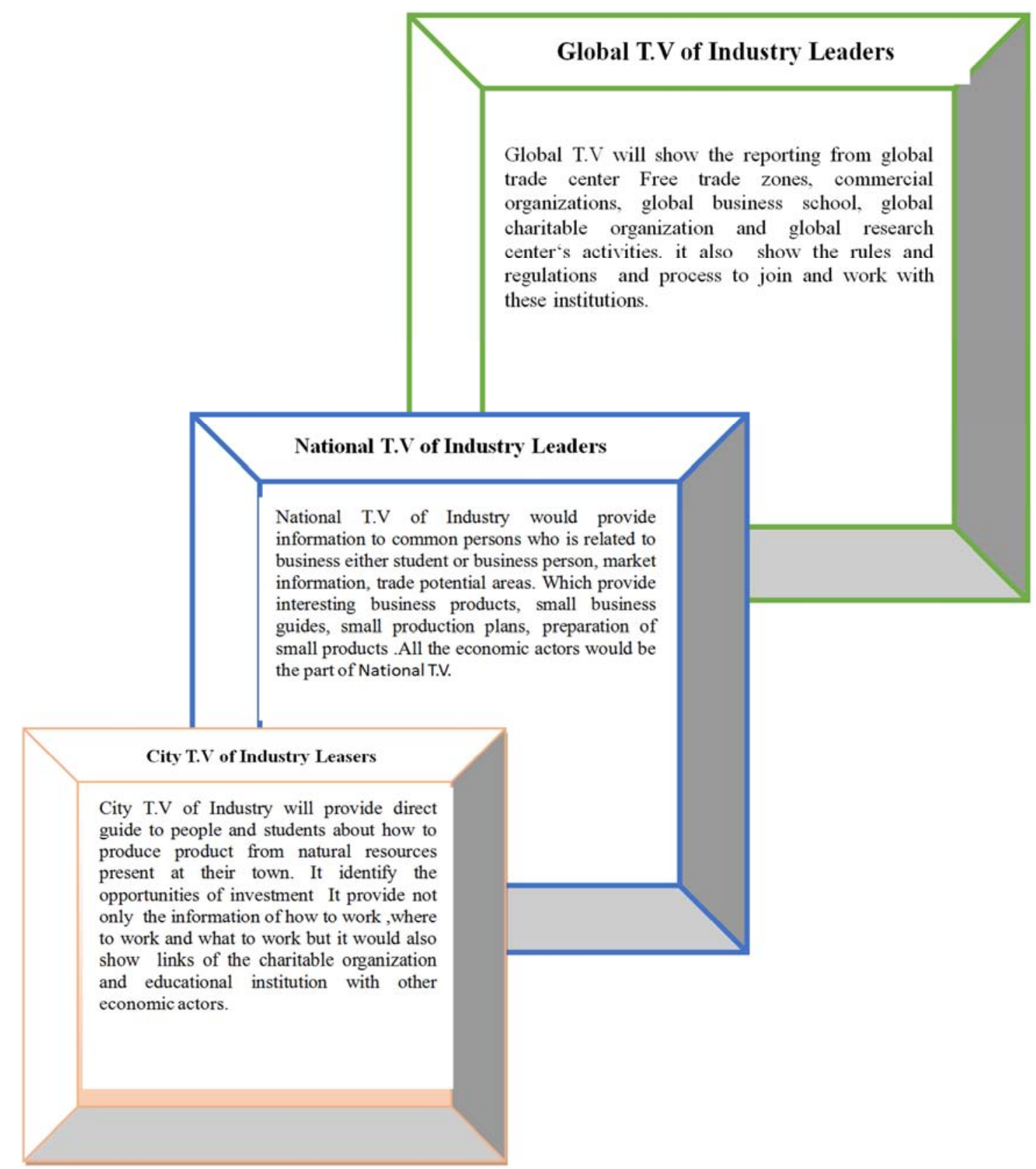

Figure 5. T. V of industry Leaders.

\section{Advanced Shape of Financial Structure}

The present institutional arrangement not be able adequately manage with today's complex business world. There is need to be batter predict and resolve the worldwide financial crises. Global financial crisis and required to be stopped and managed if occur in future [12]. To improve the financial structure we have to use our efforts strategically to pick up new ideas in business and adjustment at all level. These ideas and plans should be innovated in advertising, marketing, sales, transaction, business dealing, contract, manufacturing, industrial, and engineering, organization, designing, developing, services and updating businesses. The panel of scholar and study scientist could better understand the future and current requirements of nations regarding financials strength. Building relations among different groups and institutions would give the new shape to the financial structure to play an active role in the economic growth of all the regions.

\subsection{Shape of Local Financial Structure}

This small scale investment and businesses arrangements depends on financial resources existing in local or district level. Improvement in Local Financial Structure would become because the improvement of Country Financial Structure. The uses of local based natural resources would bring evolution and revolution in the business world. The shape local financial structure would be as under. 


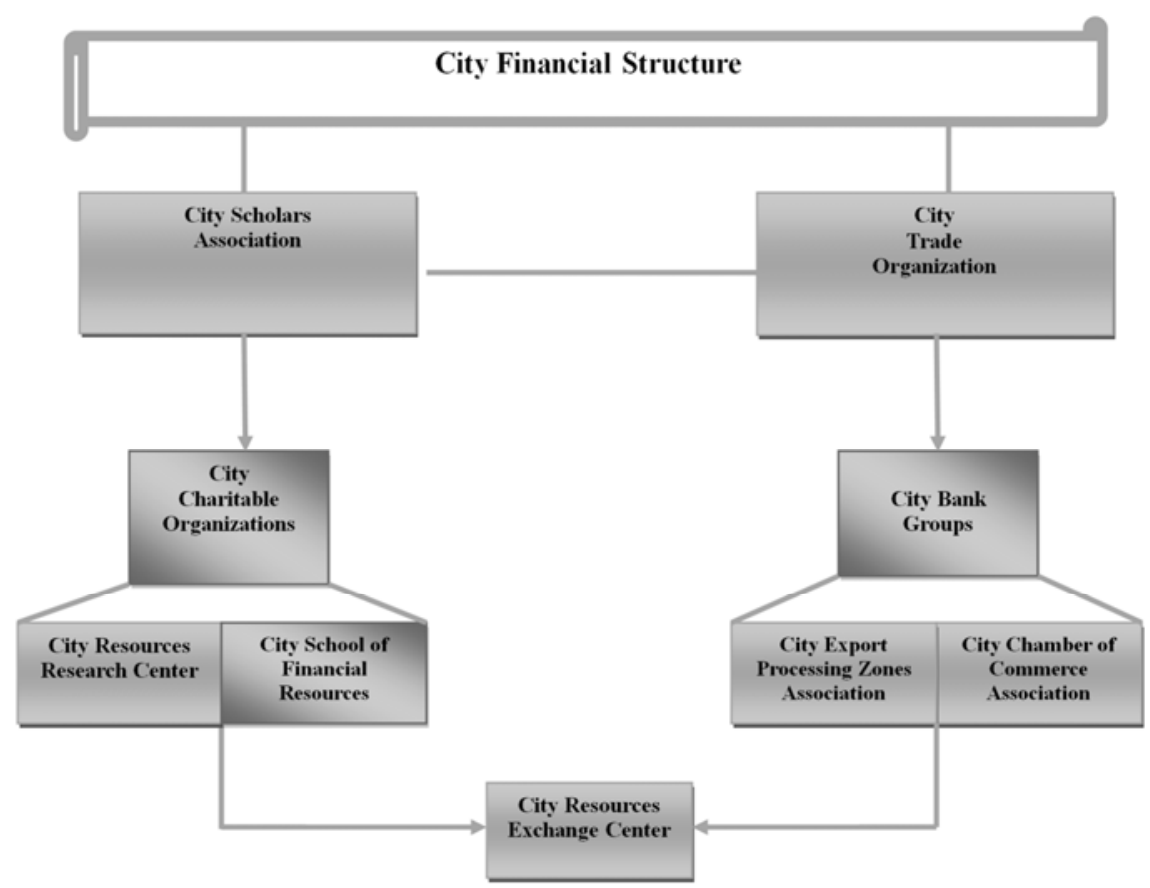

Figure 6. Systematic Links of Different Association on Local Level.

\subsection{Shape of Country's Financial Structure}

A lot of acres lands, rivers, and mountains are present untouched and unused in every country. When these groups connect systematically with each on national level on the sound base of local financial structure the growth and development will be achieved easily. Millions of small business ideas will be come from local level and billions of employment opportunities will be generated in every country, The utilization of their own resources make them dependent economically very rapidly.

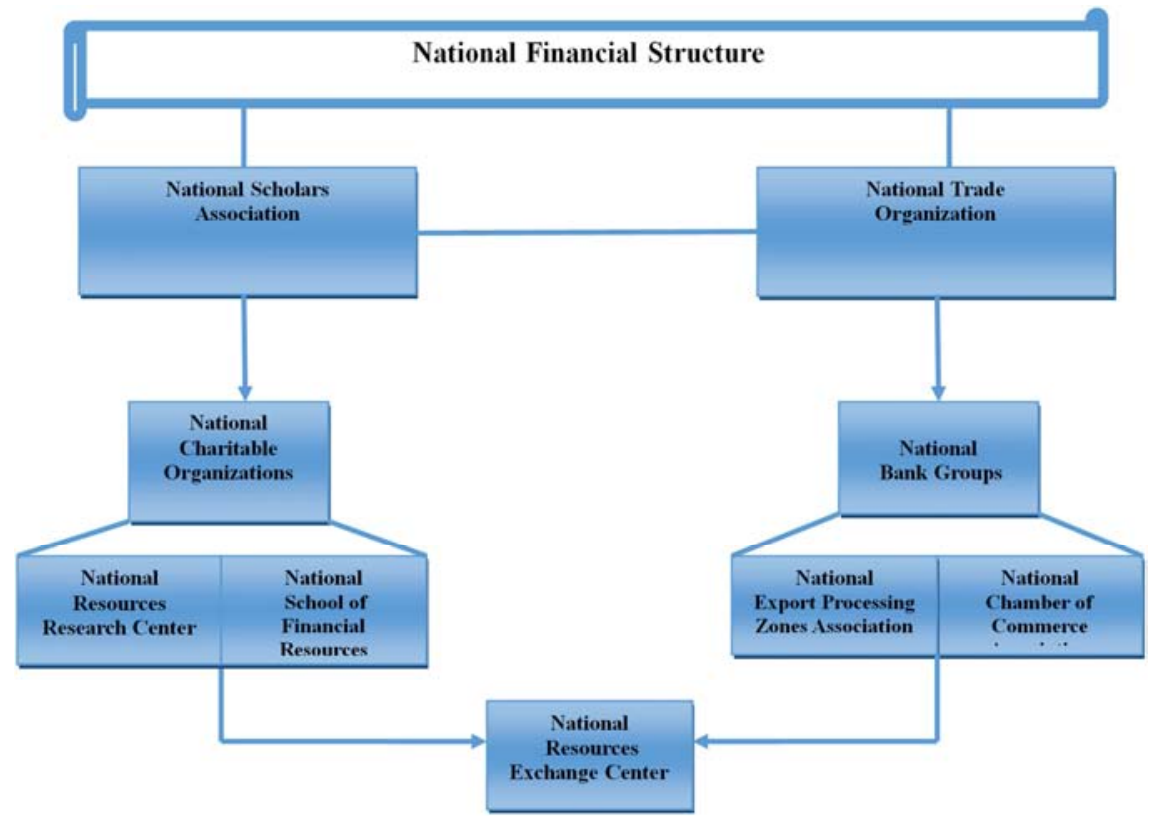

Figure 7. Systematic Links of Different Association on National Level.

\subsection{Shape of Global Financial Structure}

Worldwide arrangements of legal agreements, contracts, and association based on the internationally accepted slandered is necessary for countries and organizations, where they could be able to exchange financial resources, funds, services among each other's. After fulfilling the need of a country, the extra resources could be exchange with another country. Perfection in the local and national financial structure becomes cause to improve the global financial structure. 


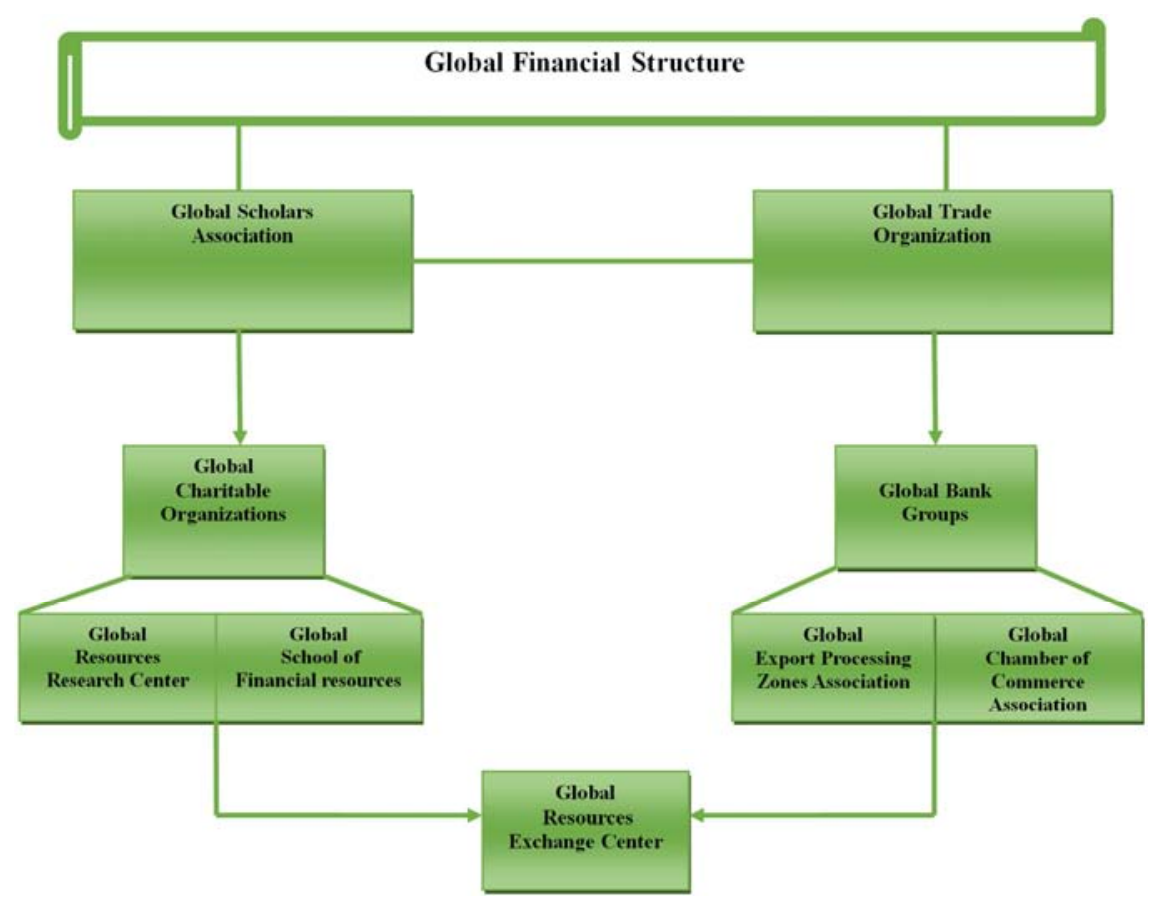

Figure 8. Systematic Links of Different Association on Global Level.

\section{Motives of Financial Structure Would Work Together Accordingly}

Adam Smith believed that "economic development depends not only wealth accumulation but also social and scientific change" and these changes will be arise when different valuable groups bring changes in their work and education system. Different valuable associations are playing their roles in economic and social in all over the world but they need guidelines and various tracks to travel together on the way of progress and economic development.

\subsection{Global Trade Organization}

Global Trade Organizations will set rules and regulation for the trade at every level. It helps the local and national trade organization to observer the trade of their areas. This trade organization will provide the track to the fallowing associations.
a. Bank Groups
b. Export Processing Zones Association
c. Chamber of Commerce Association

\subsubsection{Bank Groups}

The financial crises have become forefront area for academic and policy discussion. The writers has found that the crisis in the banking zone normally precede the currency crisis, the currency crisis than make deeper the banking crises [13]. To stay away from the any type of crises Banks can do business, on partnership bases with those organization or personals those, who want to work under export processing zones along with their services currently the banks are providing. Their business should be according to the rules set by the global trade organization. National and city trade organizations would also provide guide line to the bank groups regarding funds and partnerships deeds.

\subsubsection{Export Processing Zones}

EPZs could provide roof to both banks and small business organization. City export processing zone would play a great role bring into use the financial resources present at their areas and made commercial organization able to utilize these resources in their business operation and management. It would provide the incentives packages and infrastructure facilities to the small business and business professionals according to the requirement of that local area keep in mind the business rules. EPZs should be attractive enough for local national and foreign investors.

\subsubsection{Chamber of Commerce Association}

. All commercial organizations would have the option to work under the epzs or to independently. Chamber of commerce \& Industry would make its network more active from side to side with other institution and effort to create more opportunities of business with the EPZs, banking group, research centers and resources exchange centers. Charmers of commerce association provide information about the market, where the registered organization could buy and sell their resources, products and services anywhere on the world

\subsection{Global Scholar Associations}

Scholar Association would be responsible to guide its related association according to the vision and requirement of their Nations to make them able to work and live with the globally accepted standard. This trade organization will provide the track to the fallowing associations.

a. Charitable Organizations

b. Research Centers

c. School of Financial Resources 


\subsubsection{Charitable Organizations}

In 1970s the United States has started to establish chartable societies for the social welfare of the common people many groups welcomed this noble aim and started to contribute to solve the problem of poverty [14]. Donors, Contributors, Supporters organization and individuals have great love with humankind so that they are never ignored in the decision making regarding the welfare of the people. To execute the economic activities of the town, city, national and international level. Charitable organizations would start their work to see the human happy and established; no doubt donors always look forward to help the more and more people., Any charitable organization is wish to provide money, time and expertise would receive the guidelines from scholars as where to donate now much donate and when to donate before they registered.

\subsubsection{Research Centers}

"Learning by giving "training strategy has put down long term effects on student's learning, thinking viewpoint and aims, was developed to Increase the understanding about the social needs and nonprofit organizations [15]. These research centers, charitable organization and school of financial resources would work just like a team under the leadership of scholars. Research Centers would have the duties to provide the list of resources available not only in their own city and nation but also be responsible to deliver the list of resources available in the whole world and also identify the areas, which have scares resources.

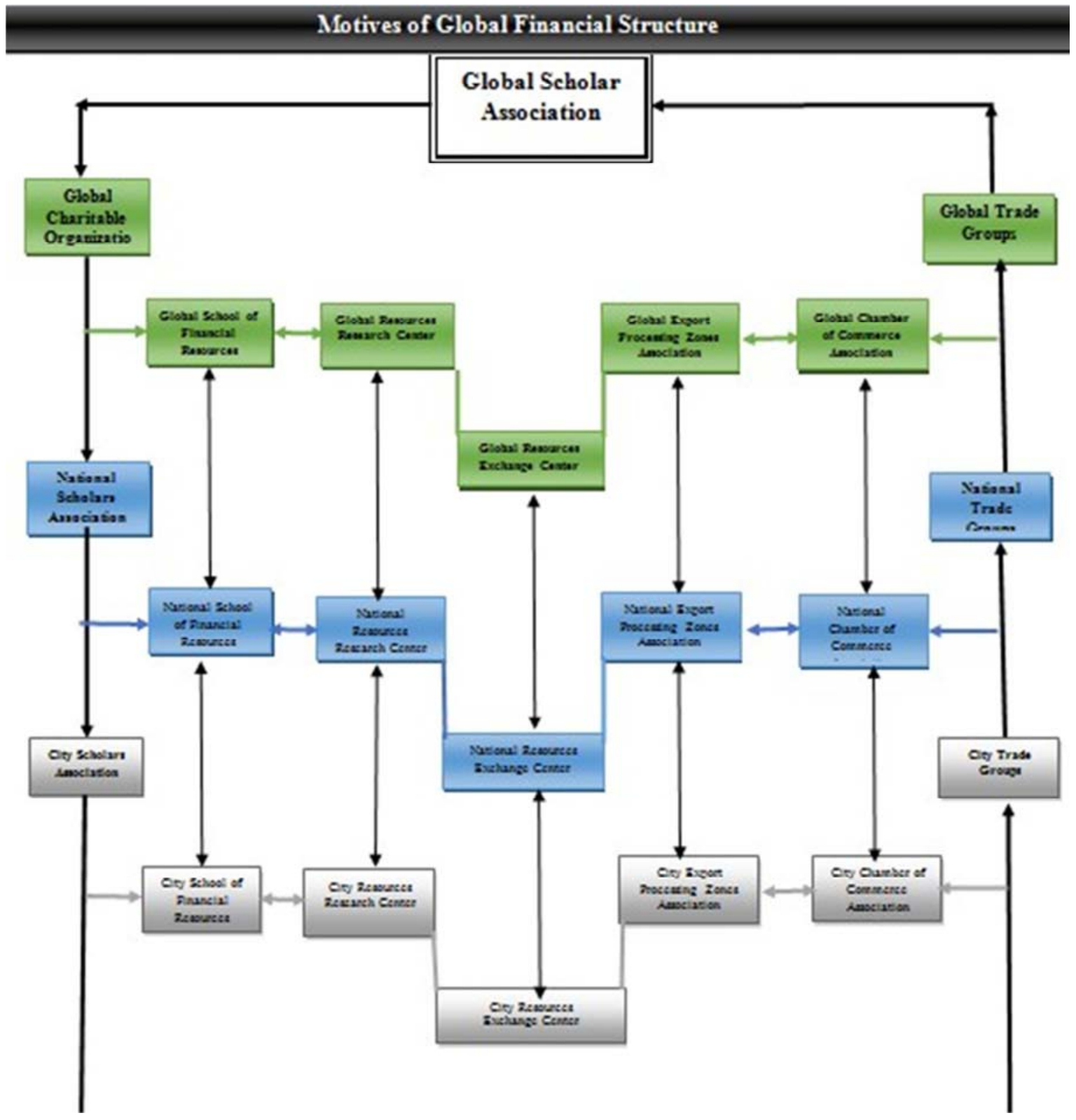

Figure 9. Links of Different Association to Make World Financial Structure.

\subsubsection{School of Financial Resources}

Global school of business could establish its branches all over the world. Students passed from the theses business school system could not get the degree by the university until he/she settled out the seven poor people to get out them from the poverty through a small business setup in other word they 
must have to create job for seven people, through a small business. Theses business would be established with the help of donation provided by charitable organization related to that university recommend by the scholars association.

\subsection{Resources Exchange Centers}

Recourse Exchange Centers would work as a hub where, interested organization could exchange their resources freely. List of bartered financial resources should be sent to panel of scholar. Educational institutions, industry T. V, charitable organizations, free trade zones and commercial organization for future guidelines and investment decisions. This exchange could have significant impact on the progress of the nations. Paper money should not be used in the resources exchange centers it should be deal through a barter system. Gold can be used as alternate medium of exchange if necessary. All resources exchange centers should be established near the airport, sea port and near or under the free trade zones. The involvement of educational institutions, donors and scholars in making financial strategies and in shaping the financial structure is very important in this age of globalization. Because these groups can help the people and nations about, how to support the others, how to do continuous struggle to increase prosperity in human lives through unlimited financial resources provided by God in our universe.

We can increase the wealth thorough the natural resources but could not increase the kindness through the wealth, until we learn respect and care of others.

\section{References}

[1] Corley, T. C. (2010). Rich habits: The daily success habits of wealthy individuals. Hillcrest Publishing Group.

[2] McGregor, D., \& Cutcher-Gershenfeld, J. (1960). The human side of enterprise (Vol. 21, pp. 166-171). New York: McGraw-Hill.
[3] Abdelal, R. (2007). Capital rules: The construction of global finance. Harvard University Press.

[4] Cole, H. L., \& Obstfeld, M. (1991). Commodity trade and international risk sharing: How much do financial markets matter? Journal of monetary economics, 28 (1), 3-24.

[5] https://www.energymatters.com.au/panels-modules/.

[6] Park, N. G., Grätzel, M., Miyasaka, T., Zhu, K., \& Emery, K. (2016). Towards stable and commercially available perovskite solar cells. Nature Energy, 1 (11), 1-8.

[7] Hamilton, K. (2006). Where the wealth of nations is: Measuring capital for the 21 st century.

[8] Davis, J. H., Schoorman, F. D., \& Donaldson, L. (1997). Toward a stewardship theory of Management. Academy of Management review, 22 (1), 20-47.

[9] García, J. M. R. (2001). ScientiaPotestasEst-Knowledge is Power: Francis Bacon to Michel Foucault. AngliaZeitschriftfor English Philology, 119 (1), 1-19.

[10] Devlin, M., James, R., \&Grigg, G. (2008). Studying and working: A national study of Student finances and student engagement. Tertiary Education and Management, 14 (2), 111-122.

[11] Ellis, L. W. (1988). What we've learned: Managing financial resources. Research- Technology Management, 31 (4), 21-38.

[12] Eichengreen, B. J. (1999). Toward a new international financial architecture: a practical Post-Asia agenda. Peterson Institute Press: All Books.

[13] Kaminsky, G. L., \& Reinhart, C. M. (1999). The twin crises: the causes of banking and Balance-of-payments problems. American economic review, 89 (3), 473-500.

[14] https://www.investopedia.com/contributors/759/.html.

[15] Olberding, J. C. (2012). Does student philanthropy work? A study of long-term effects of the "Learning by Giving" approach. Innovative Higher Education, 37 (2), 71-87. 